\title{
Alliance Vulnerability and its Remedies: Tracing the Abandonment of Kurds and South Korea Under the Trump Administration
}

\author{
Kiljoo Ban
}

\begin{abstract}
Alliances serve as a security guarantor but this is not always the case in the sense that allies struggle with the of abandonment and entrapment. The U.S. abandoned its local ally in northern Syria, the Kurds, by withdrawing its soldiers in October 2019, allowing the Turkish military to bomb them. An asymmetric partner vows to ally with a strong partner even in a situation where the former is aware of the latter's potential betrayal. This bond can only result in tragedy. Which condition makes abandonment and/or entrapment more likely? Two key variables serve as the mechanism for alliances between actors-power parity and the nature of the bond, both of which lead to four different outcomes. A symmetric and institutionalized alliance is the most stable and thus, least likely to result in abandonment and entrapment. By contrast, an asymmetric and non-institutionalized alliance is likely to be the most tragic. This analysis offers insight into political and policy implications. In particular, the lessons learned from the U.S.'s abandonment of the Kurds might help provide the Republic of Korea (ROK) to avoid this tragic step a scenario they experienced once before in 1950 shortly before the outbreak of the Korean War.
\end{abstract}

Keyword: asymmetric alliance, abandonment, institutionalization, the Syrian Kurds, the Korean War, the ROK-U.S. alliance

* Kiljoo Ban (raybankj@inha.ac.kr) is a research fellow in the Center for International Studies, Inha University. He received his Ph.D. degree in political science from Arizona State University (2011). His research interest is hegemonic competition, alliance, middle power diplomacy, and maritime strategy. He has written four books (one book with six other coauthors) and more than 30 articles, including "The power of cultural weapons in counterinsurgency: South Korea's Jeong culture and its effectiveness in Vietnam," Small Wars and Counterinsurgencies (2021), "Aircraft Carrier Balancing in Northeast Asia and South Korean Carrier Program: Power, Threat, and Function," The Korean Journal of Defense Analysis (2021). 


\section{INTRODUCTION}

Amid a stronger allied state's disrupting policy to bash allies, swayed by domestic politics, which hich alliances survive and which do not? Alliances serve as one of the longstanding foreign policies, which should not be affected by domestic partisan politics. Meanwhile, when an alliance is swayed by domestic politics, it is less likely to be cohesive and sustainable. The Trump administration showed how domestic politics can harm alliance cohesion, one of the key security entities in international politics. While placing more emphasis on the "America First" policy, the Trump administration did not hesitate to bash America's allies and even abandon them (Tiezzi 2020). In 2019, the Trump administration abandoned the Syrian Kurds, a key ally in the battle against IS (Islamic State) fighters. In the 2018-20 period, as the Trump administration identified North Korean dictator Kim Jong-un as its friend, it ironically sent a raft of signals to South Korea that it cannot reconfirm its security commitment (Cha 2019).

Although the Trump administration punished all American allies for its egoistic "America First" policy, targeting domestic audiences, the US-Kurdish alliance faced an alliance breakdown but the Republic of Korea (ROK)-U.S. alliance confirmed the need to maintain its cohesion and(survived). What makes the difference? A level of power parity and institutionalization explains the difference in these two cases. When an alliance is loosely institutionalized and power is more unbalanced, alliance decoupling swayed by domestic politics is likely to go from bad to worse.

The Kurds in Syria, a non-state actor, was an extremely asymmetric ally to the U.S. and the U.S.-Kurds alliance remained largely uninstitutionalized. A small actor, inevitably, is likely to be eager to ally himself with a strong actor despite the nature of a makeshift bond. The former is enthusiastic to be allied with the latter even with the understanding of the potential for the latter's betrayal in the foreseeable future. The Kurds, an asymmetric partner, chose to ally with a strong partner but inherently ran the risk of the latter's abandonment particularly due to a lack of alliance institutionalization. These puzzles are thought-provoking in exploring alliance maintenance.

In contrast with the case of the U.S.-Kurds alliance, the U.S.-South Korea alliance remained manageable despite Trump's bashing. Power parity and institutionalization were in full swing to prevent alliance decoupling. South Korea remained the 10th largest economy in the world and one of the major powers in Northeast Asia (Yonhapnews Agency 2020). Moreover, the U.S.-South Korea alliance has been institutionalized over seven decades following the Korean War, signing the treaty, and training under the same military command, 
the ROK-U.S. Combined Forces Command [CFC] (Jung 2019). Thus, in the wake of the Trump administration's bashing, the ROK-U.S. relations were deadlocked but did not lead to alliance decoupling. Other players such as the U.S. Congress and the military strove to stress the importance of the ROK-U.S. alliance to revive alliance cohesion.

A lack of power asymmetry and a high degree of institutionalization encourages the new U.S. administration to survive the rocky ROK-U.S. alliance. On November 12, 2020 when U.S. President-elect Biden had a phone talk with South Korean President Moon, he stressed Washington's "defense commitment to South Korea" (Welle 2020). This posture shows that a different track of domestic politics attempts to fix a foreign policy bungled by domestic politics. This changing posture is boosted by power parity and institutionalization. Historically, when South Korea remained extremely weak and the U.S.-South Korea alliance remained non-institutionalized, it was abandoned easily by the U.S. similar to the Syrian Kurds. In 1950, Washington abandoned Seoul by excluding South Korea in the Acheson Line, which tragically led to the Korean War.

This paper attempts to piece together a jigsaw puzzle on alliance vulnerability, that surfaced in the Trump era. To that end, it develops an analytical framework of the dilemma of a makeshift asymmetric alliance following the literature review of alliance formation and maintenance. Then, the cases of the Syrian Kurds and South Korea are explored from a viewpoint of maintaining an alliance with the U.S. Finally, scholarly and policy implications are laid out while focusing more on the impact of the U.S.'s abandonment of the Syrian Kurds on the ROK-U.S. alliance.

\section{LITERATURE REVIEW AND ANALYTICAL FRAMEWORK}

\section{Literature Review}

International Relations (IR) scholars examine alliances in two broad ways: the origins of alliance and its maintenance. First, what provides for the formation of alliances? One explanation is that states not only make internal efforts to bolster their capabilities but also try external efforts to make alignment with other states in their attempt to guarantee their survival under anarchy (Waltz 1979, 118). The external efforts are in line with the balance of power mechanism based on the military bond against the most powerful state. Another explanation is that alliances are formed under the logic of the balance of threat, making military bond aligned against the most threatening state because fighting with allies are likely to increase the probability of winning wars (Walt 1987; Morrow 
2000; Gibler and Wolford 2006; Kimball 2010, Johnson 2017). Unlike both explanations, the balance of interests is laid out to explain the reason why states form alliances (Schweller 1994). Alliance formation is also explained by a bargaining process in the international system (Snyder 1997).

Second, alliance maintenance serves as the other axis of alliance politics. Although alliances are formed for various reasons, they frequently fail to be maintained or remain cohesive. Thus, which factors drive alliances to be more sustainable or more vulnerable is at the center of the puzzle. Free-riding is laid out as one of the harmful factors to alliances' maintenance and thus, the theory of collective goods is proposed (Goldstein 1995). Similarly, which allies, smaller or larger, seem more likely to free-ride is examined (Plümper and Neumayer 2014). How much a strong ally's coercion has an impact on alliance cooperation is also traced in the case of the North Atlantic Treaty Organization (NATO) (Kupchan 1988). Internal competition among allies is taken into consideration as one of the factors to affect alliance cohesion and "collective capability" (Niou and Zeigler 2019). The impact of a gray actor as a third party on alliance cohesion is investigated while China is characterized as a gray player (Ban 2020).

This research belongs to the second area, alliance management, because of its focus on how abandonment works differently. In this line of effort, dilemmas driven by fear of entrapment and abandonment have been examined in this school of alliance politics (Snyder 1984). The fear of entrapment and how to grapple with it is examined through the case of the U.S.-South Korea alliance (Kim, 2011; Park 2017). The fear of abandonment explains the dilemma of alliances that a weaker ally could be betrayed by a stronger ally in terms of the latter's security commitment. Some argue that democracies are less vulnerable to the option of abandonment (Choi 2012). recent studies attempt to explore this dilemma while focusing more on the mechanism of gray-zone conflict (Bosack 2020).

Trump administration's America-First mindset has weakened traditional alliances, giving rise to a fear of abandonment. Thus, the literature on the alliance crisis under Trump is at the forefront. While noting that Trump demanded NATO allies to increase defense spending and threatened to separate from NATO without it, Richter (2021) argues that the U.S. wreaked havoc on the robustness of NATO. Under the Trump administration, Japan was eager to save the U.S.-Japan alliance. O'Shea and Maslow (2020) claim that despite Abe's emphasis on "making the alliance even greater," Trump's bashing causes the discourse of autonomy to be revitalized. The ROK-U.S. alliance was also under the fear of abandonment by Trump, raising the question of alliance sustainability. Yeung (2021) maintains that despite Trump's reluctance of security commitment, South Korea will not be abandoned because of its geopolitical value to deter North Korea and guarantee 
American presence in the Indo-Pacific region.

Meanwhile, the case of Syrian Kurds abandonment by Trump remains largely unexplored. Furthermore, the logic of survival of the ROK-U.S. alliance under Trump's bashing overplays the geopolitical dimension and fails to examine the underlying driver to restrain Washington's abandonment of Seoul.

\section{Analytical Framework}

The U.S. has been allied with many states for many reasons: winning wars, maintaining hegemony, or maximizing its interests. Whatever the origins of these alliances may have been, there is consensus that the U.S.'s abandonment is an unlikely scenario, as opposed to authoritarian states. This prestige of the U.S. as a benevolent hegemon, however, seems to be less paid attention to in the "America First"-led Trump era. Washington demanded more money from its allies in terms of defense-cost sharing. In this way, too much emphasis on its own self-interest increases the fear of abandonment. By the same token, the traditional concept of alliances in international politics has been stumbling and even abandonment has become a serious issue to international security. Although the Trump administration is is facing skepticism-in terms of alliance calculation, a state's own interest-seeking posture should not be taken as the exception. Despite the Trump administration's coherent policy of abandonment, some alliances have survived and others have not. Which conditions make alliances less swayed and more sustainable? Tracing answers to the puzzle sheds light on how to maintain more stable alliances in the future as well in this stumbling era.

How is alliance conceptualized? Alliances are normally defined as commitments to deter military attacks from enemies (Fearon 1997; Morrow 1994; Smith 1998). Meanwhile, while highlighting two objectives of alliances, Benson (2011) lays out a new alliance typology: "unconditional compellent, conditional compellent, unconditional deterrent, and conditional deterrent." An alliance is here conceptualized in three ways to answer the research puzzle: actors, purpose, and scope. The alliance is defined as "the state of being allied," or "a bond or connection between families" (Merriam-Webster). The former definition regards actors being allied as states, whereas the latter definition includes even non-state actors as players for the alliance. In the post-911 era, even great powers seek alliances with non-state actors or small ethnic groups driven by the complex mechanisms of international politics. As such, this analysis includes non-state actors in terms of the conceptualization of alliances. Second, in addition to the types of actors, the purpose or aim for an alliance to be made needs to be specified. Actors may cooperate for their profit in an economic sense or their survival in 
a security sense. Although the two aims often overlap, cooperation for security is analyzed here as a motive for alliances because security always has priority over the economy in terms of survival.

Third, the scope of the alliance varies, ranging from tactical cooperation to strategic cooperation or from short-term to long-term. States may attempt to ally with stronger states for short-term survival even though they are aware of the inherent uncertainty for long-term survival. Besides, stronger allies may attempt to just use weaker allies for their own tactical purposes rather than for their strategic aims. Similarly, alliances can be formed formally through institutional agreements or just informally with less bonding effect. Neorealists of IR pay tremendous attention to the structural explanations of the formation of alliances. Their parsimonious theory, however, leaves the dynamic nature of alliances like all of the above unexplained. The neoclassical-realist approach plays a role in filling the gap left by neorealists. To that end, a wide scope needs to be defined in the alliance, which ranges from loosely-formed short-term cooperation to longstanding cooperation.

Pound for pound, an alliance, or the bond in a broader sense here for analytical purpose, is conceptualized as the status of alignment between actors, including states and non-state actors, formally or informally in their efforts to seek security directly or gain the byproduct of security-driven activities. In particular, a provisional-made loose bond or connection is analyzed here as the particular bond, aimed at examining the underlying logic of abandonment.

With the analytic definition of alliance and the aforementioned mechanism in mind, a typological matrix is proposed in its efforts to unearth the dilemma of a makeshift asymmetric alliance (see Table 1). The congruence of two independent variables, power parity and the nature of the bond, leads to four outcomes in terms of the degree of alliance maintenance. Power parity refers to how equivalent both partners are in terms of power and an actor's position in the world. A factor of power implies how allies maintain economic and military symmetry. Although allies find it hard to maintain perfect equilibrium in terms of capabilities, a degree of asymmetry can be compared between cases when taking into consideration several dimensions like the status of an ally as an actor-state or non-state or its relative economic and military capabilities. An actor's prestige is differentiated among non-state actors without sovereignty, weak powers, middle powers, or great powers. Those clarified definitions are pivotal to measure proposed variables as well.

The nature of the bond refers to how institutionalized their relations are: temporarily-made conciliatory gestures, talks or treaties for cooperation, or a culturally, organizationally, or militarily-embedded bond. A tactical level of 
military coordination under an imminent threat is far from an institutionalized bond. In contrast, treaty allies are under an institutionalized bond. Meanwhile, institutionalization does not end in establishing treaties but goes further through cultural, strategic, and political levels of coordination. The level of institutionalization is measured where alliances are treaty-based or not and multiple levels of connections are employed. When an alliance is highly institutionalized, the administration's policy of abandonment can be restrained or checked by other actors including the congress and the military authority.

The dependent variable is alliance vulnerability, ranging from vulnerable to decoupling into cohesive. In particular, the dependent variable focuses on which alliances survive when one allied state attempts to abandon the other allied state. Four outcomes of the dependent variable need to be clarified. Condition A is met when partners' relations are symmetric in nature but an alliance is not institutionalized. This bond remains vulnerable due to its non-institutionalized nature formed with the short-term opportunity. Both partners are fundamentally symmetric in power, but their cooperation benefits the least from the institutionalized bond mechanism. When they face disagreement, they are most likely to abandon their ally in the most convenient way possible. This abandonment is likely because both symmetric allies rarely rely on each other for their survival and they are less dependent on an alliance than asymmetric allies. The choice of abandonment renders more friction between both allies but at the same time, does not pose a serious threat to their own security. The internal rivalry between symmetric partners prevents one actor from being entrapped by the other actor's interest-seeking activities.

Condition B, serving as the best case, is made when allies' relationships are symmetric and an alliance is embedded in their cultural, military, and organizationally institutionalized mechanism with a long-term outlook. The archetypal case here being two democracies with symmetric power that share cultural and historical identity maintains a high degree of alignment and cooperation for examples like the relationships between the U.S. and the U.K. Power symmetry and shared values make allies less risky to both abandonment and entrapment. When two allies with a high degree of institutionalization take each other as longstanding friends, both states are strongly reluctant to abandon their allies. At the same time, neither state is weak enough to be entrapped by its ally's interest-seeking artifice. In short, both abandonment and entrapment are least likely because benefits from an alliance are relatively equally distributed. An alliance is most likely cohesive and sustainable, which remains the closest to the bloodshed alliance.

Condition $\mathrm{C}$ drives partners to become the worst bond, which is met when 
allies' relations are asymmetric and an alliance is tactically formed with a short-term, non-institutionalized purpose. This extreme symmetry hinders both partners from serving as equal partners and a lack of institutional foundation fails to fill the gap driven by this asymmetry. Alliances formed under this condition most likely aim at tactical gains, not at strategic gains. The benefits of an alliance created by this condition are not equally distributed The relationship is far from reciprocal. They simply seek a temporal or makeshift agreement for short-term interests and by doing so, their shared interests are short-lived. Partners under this $\mathrm{C}$ mechanism remain unguarded to alliance decoupling at all times.

On the one hand, a strong partner seeks a temporary bond with a weaker partner not for a broad range of political gains but simple tactical gains. Thus, the stronger partner does not hesitate to abandon the weaker partner when the latter is not tactically useful any longer. Its abandonment does not pose a great threat to its security but rather contributes to its autonomy and policy flexibility, which brings itself to greater strategic gains. In this sense, this abandonment is the trade-off between tactical loss and strategic gain. On the other hand, a weaker partner seeks an alliance with a stronger partner while hoping that this relation maintains as long as it can. A weaker partner, however, is already aware of the foundation of this bond and thus, it is fearful of the stronger partner's abandonment from the outset. Despite this fact, a weaker partner shakes hands with a stronger partner because the former's survival may not be possible without such a security bond. Thus, both abandonment and entrapment are most likely to be made under the alliance created by this condition. In 2019, the U.S.-Kurds alliance was ruptured too easily under this ' $\mathrm{C}$ ' mechanism.

Condition D makes an alliance remain vulnerable while partners' relations are asymmetric but an alliance is institutionalized and maintained for a relatively long period. On the one hand, a stronger ally is reluctant to abandon a weaker ally because of the accumulated benefits of the longstanding alliance. On the other hand, a weaker ally is most likely to be entrapped by a stronger actor's interest-seeking activities because the former is heavily reliant on the latter in an asymmetric way. Alliances under this condition seem likely to serve well with an ironclad-like nature thanks to institutionally ingrained characteristics. These alliances, however, can still stumble despite their longstanding nature if the weaker ally cannot afford to do more for the stronger ally. Frictions can trigger at any time due to the asymmetric nature of alliances. The U.S.-South Korea alliance faced this obstacle in the post-Korean War period. 
Table 1. The Dilemma of a Makeshift Asymmetric Alliance

\begin{tabular}{|c|c|c|c|}
\hline \multirow{3}{*}{ Power parity } & \multirow[b]{2}{*}{ Symmetric } & \multicolumn{2}{|c|}{ The nature of the bond } \\
\hline & & $\stackrel{\text { A }}{\text { (Vulnerable) }}$ & $\begin{array}{l}\text { B: Best Scenario } \\
\text { (Cohesive) }\end{array}$ \\
\hline & Asymmetric & $\begin{array}{l}\text { C: Worst Scenario } \\
\text { (Decoupling) }\end{array}$ & $\begin{array}{c}\text { D } \\
\text { (Vulnerable) }\end{array}$ \\
\hline
\end{tabular}

Case selection matters more in qualitative analysis. The qualitative methodology of this examination follows the logic of 'most different cases.' To that end, US-Kurdish relations are selected as the case of decoupled alliance and the ROK-U.S. relations are chosen as the case of the survived alliance under the Trump administration's policy to abandon its allies. An initiating trigger of making alliances stumbling remained in the same way, one allied state's abandoning behavior. One alliance survived but the other failed to survive. The different outcomes show that there are other variables at work simply beyond Trump's disrupting policy. Meanwhile, the case of South Korea serves as a crucial case in the sense that its conditions have been moving in the proposed quadrant from $\mathrm{C}$ to $\mathrm{D}$ into $\mathrm{B}$.

\section{TRACING U.S. ABANDONMENT OF THE SYRIAN KURDS UNDER THE 'C' MECHANISM}

\section{Facts on the Ground}

In 2019, the U.S. betrayed its ally, the Kurds in Syria without being guarded under the condition of power imparity and non-institutionalization. What drove them to this decoupling? On October 12, 2019, Turkish-backed militiamen brutally killed Hevrin Khalaf, a female Kurdish political leader in Syria. Ms. Khalaf served as an iconic figure for both the alignment between the Kurds in Syria and the U.S. and the Kurdish-Arab friendship (Burc 2019). This incident has changed her from the symbol of cooperation with the U.S. to one of betrayal on the part of the U.S. On October 3, 2019, Ms. Khalaf, the secretary-general of the Future Syria Party, negotiated with U.S. partners who reportedly promised to offer a security guarantee for the Kurds in northern Syria. U.S. military soldiers

\footnotetext{
${ }^{1}$ As for the logic of a methodological logic in qualitative analysis, see Gerring (2007).
} 
fought together with their allied Kurdish-led Syrian Democratic Forces (SDF) against the Islamic State (IS). The 11,000 Kurdish fighters who fought with U.S. soldiers, have been killed in action in this war against the IS (Lamothe, 2019).

In less than three days after the negotiation between Ms. Khalaf and her American counterpart, however, the U.S., which is often referred to as a benevolent hegemon or a leading state for human rights in the world, shockingly betrayed the Kurds without any early notification. On October 6, Washington announced that "the United States would not stand in the way of a Turkish military offensive to remove the SDF near Turkey's border" (Lamothe 2019). This announcement provided Turkey with a window of opportunity to bomb the Kurds in Syria, America's ally. ${ }^{2}$ On October 9, prior to the actual attack by Turkey, U.S. President Donald Trump, reportedly, "acquiesced to the Turkish operation" in a direct call with Turkey's President Erdogan on October 6 by "agreeing to move American troops out of Turkey's way" (Hubbard \& Gall 2019). On October 13, U.S. Defense Secretary Mark Esper maintained that "President Trump ordered a withdrawal of American forces from northern Syria" (Barnes \& Schmitt 2019). Washington had withdrawn 50 U.S. soldiers from the border area before Turkey launched its offensive, which was a clear posture of betrayal to the Kurds. No players in the U.S. opposed Washington's decision, which made the alliance unguarded.

Consequently, Turkey regarded all of these indications as a green light to attack the Kurds in Syria and began their bombardment of northern Syria. ${ }^{3}$ Turkey's offensive killed 600 people and forced 300,000 people to flee from their homes. The U.S.'s betrayal is clearly tragic to the Kurds but at the same time, might not be the only case in world politics. In other words, all allies are vulnerable to a strong ally's betrayal. Even South Korea, a rapidly-growing middle power in the world, has experienced such an event. In 1950, while abandoning South Korea, the U.S. unexpectedly excluded South Korea from its defense line in the region, providing North Korea with a window of opportunity to invade South Korea. Thus, the Kurds' tragedy should not be taken as an extremely rare case in world politics.

Were the Kurds unaware of the possibility for the U.S. to betray itself? If the Kurds were already aware of this risk, why did it attempt to form an alliance with

\footnotetext{
${ }^{2}$ For an initial process of Turkey's engagement in the Syrian civil war, see Parlar Dal Emel(2016).

${ }^{3} 15$ million Kurdish are estimated to live in Turkey and they are eager to autonomously live from the Turkish government. The Kurdistan Workers' Party (PKK), which was established in the 1970s in Turkey, is aimed at founding its own nation-state, which renders Turkey haunted. In the meantime, the PKK maintains a connection with the Kurds in Syria (Kirby 2019). Turkey regards the bond between the Kurds in Syria and the PKK in Turkey as a serious existential threat particularly in the event that these two parties establish an autonomous entity on the border between Turkey and Syria. This idea serves as the underlying background for Turkey's offensive.
} 
the U.S.? What dilemma could the allies have struggled with? Which dynamics drive a stronger ally to abandon a weaker ally? Tracing the answers to the puzzle sheds light on how to get out of the alliance dilemma. The Kurds in Syria were an extremely weak partner to the U.S. due to a hugely asymmetrical power gap. The Kurds are not, themselves, even a state but a small group of tribes or militias. On the one hand, the uncertain nature compelled it to eagerly seek an alliance with the U.S. for its survival in the autonomous region. On the other hand, the U.S. needed local allies who were familiar with the terrain and the local population to win small wars aimed at maintaining its sphere of influence as a hegemon. In this vein, the U.S. abused its hegemonic power by making its weak partner entrapped in the war intended for maximizing its interests.

To make matters worse, once the war became unhelpful for its national interests, the U.S. simply abandoned the Kurds. If here, the counterpart had not been the Kurds, an asymmetric partner, but a great power, what would have happened to them regarding the logic of entrapment and abandonment? All states seek their national interests. They seem least likely to make an alliance while they have priority over their own national interests. When their allies are more symmetric partners and the alliance becomes more institutionalized, however, the logic of entrapment and abandonment is less likely to happen. What drives this mechanism to work? Since every state seeksto maximize its own interest, mutual benefits matter to sustain an alliance. When allies are more symmetrical, they can help each other more reciprocally. In addition, when an alliance functions as an institution, allies seem less likely to be controlled by a individual person's beck and call because institutionalization promotes allied actors as a whole, not as individual leaders, in order to stick together. Thus, long-term gains have priority over short-term gains, making them less vulnerable to risks of abandonment and entrapment.

\section{Explaining the Logic of U.S.'s Abandonment of the Syrian Kurds in 2019}

Before a deep dive, independent variables of the US-Kurdish alliance need to be discussed. First, in terms of power parity, this alliance remained extremely asymmetric, serving as the worst-case scenario of the proposed Quadrant on alliance maintenance. In contrast with the status of the U.S. as a hegemonic power, the Syrian Kurds remained a non-state actor without sovereignty or full autonomy. The Syrian Kurds were stricken with poverty and faced insecurity. To top it off, its prestige was even lower than weak states under the situation of ill-functioning autonomy or governance. Second, when it comes to the nature of the bond, this alliance remained ill-institutionalized because of its temporarily tactical level of operational coordination under imminent threat. Thus, it neither 
remained under treaties nor the strategic level of coordination. Likewise, Americans and Syrian Kurds have a shared understanding of cultures and politics.

The military alignment between the U.S. and the Kurds in Syria is akin to the makeshift bond in nature. The Syrian Kurds are not a state actor but a small minority group that seeks more autonomy in the region, whereas the U.S. is a hegemonic power that intervened in the Syrian Civil War driven by great power politics. This was the underlying mechanism that differs from the conventional alliance in international politics. This bond inherently serves as the most vulnerable one.

When Syrian citizens went to the streets to march against the Assad regime, the dictator Asaad decided to violently suppress them, leading to the Syrian Civil War. Despite Assad's cruel attacks on his citizens, Russia, Iran, and Hezbollah have supported the Syrian regime throughout the war. By contrast, rebel groups, such as Salafi jihadists and the SDF, fought against the Assad regime. In the meantime, the U.S. began to intervene in the civil war through airstrikes on the Assad regime in 2014. In particular, the U.S. allied with the SDF and has thus supported the Syrian Kurds militarily and financially since 2015. In 2016, the U.S. Special Forces were stationed in northern Syria and fought together with the Kurds against IS guerrillas. A local ally is effective and necessary even to great powers, particularly in unconventional war. In this sense, the U.S. benefitted from Kurdish fighters loyal to its military when fighting the IS guerillas in the Syrian Civil War. The Kurdish local ally helped the U.S. maintain a certain level of leverage in the region (Hubbard, Savage, Schmitt, and Kingsely 2019).

The SDF militias are mostly from the People's Protection Units (YPG). When the U.S. withdrew its troops from northeast Syria in October 2019, Turkey was allowed to dislodge the YPG. Two vital interests for the Kurds in Syria are security and autonomy and their bond with Americans in the region is aimed at both interests. They had no choice but to partner with America despite its unstable nature. The U.S.'s betrayal almost pushed the Kurds to lose both interests, though. As a result, the Kurds, again, had to make a very reluctant decision and partnered with the Assad regime. This attempt might help the Kurds seek security thanks to the regime's role as a security guardian but in return, they will lose much autonomy in the region as the autonomy-security trade-off model shows. ${ }^{4}$ To make matters worse, this bond is also makeshift in nature.

This type of makeshift bond remains the most vulnerable to alliance

\footnotetext{
${ }^{4}$ Similarly, The Economist (2019, October 24) states that "The YPG had no choice but to seek protection from Bashar al-Assad, Syria's dictator, and surrender most of its self-rule in return."
} 
decoupling at all times. The Kurds, who used to be tactically allied with the U.S., were shocked, saying that "America stabbed us in the back $\cdots$ we were betrayed" (Gol 2019). A non-state actor is fundamentally not an equal partner to great power and in being so, it is hard for two partners to become an institutionalized alliance. The tactical level of bond formed under the huge power asymmetry made both abandonment and entrapment the most likely. As opposed to the Syrian Kurds' aspiration towards more autonomy within Syria, the Trump administration militarily exploited local forces to make the region under American influence (Aziz 2020, 12-14). That explains why U.S. special envoy James Jeffrey defined this relationship as "tactical and temporary" (Aziz 2020, 14). A weaker non-state partner had no choice but to engage with the U.S.-led great-power politics and ran the risk of being abandoned. In the short-term, the Kurds sought their survival and in the long term, they wanted the U.S. to support their vision of an independent state. The Syrian Kurds, however, failed to gain even the short-term gain by the temporal alliance with the U.S. This is the tragedy of a makeshift asymmetric alliance.

The U.S.'s abandonment motivated the Kurds to align with the Syrian government under the brutal leader al-Assad, the U.S.'s enemy (Hubbard, Savage, Schmitt, and Kingsley 2019). The Kurds may already be aware of the nature of the temporal alignment with the Assad regime once again. Asking for help from Syria, however, would be inevitable for their survival, even if it is short-lived. The Kurds' frustration is understandable but the makeshift bond with Mr. Assad only seems to make them vulnerable once again. More importantly, the U.S.'s betrayal made the alliance mechanism stumble in the worldview as well as in Syria.

\section{Ruptured Bond between the U.S. and Osama bin Laden-led Guerillas in Afghanistan}

When power imparity is huge and its relations remain non-institutionalized, this decoupling could be in full swing anywhere. This is what happened to the U.S.-al-Qaeda bond in Afghanistan. On September 11, 2001, al-Qaeda made a surprise attack on mainland U.S., an event that shocked the world and changed. Its origins, however, trace back to the Afghanistan war (1979 to 1989) when a small group of guerillas in Afghanistan was temporarily aligned with the U.S. under the name of Operation Cyclone, which the U.S. Central Intelligence Agency (CIA) helped Afghan Mujahideen guerillas militarily as well as financially in response to the Soviet Union's intervention in Afghanistan (Bergen 2002, 68). During this time, Osama bin Laden, the leader of al-Qaeda, benefitted from the CIA's support and effectively trained guerilla fighters at the border town of Khost to lead them in Afghanistan (The Guardian 1999). 
This kind of partnership between a state and a guerilla group is inherently susceptible to political situations. There is huge power asymmetry between a great power and a guerilla group. In addition, the alignment between the two actors was made under tactical considerations rather than a strategically-driven purpose. This bond was intended to contain the Soviet Union, the U.S. rival in the bipolar world, but was not far off from America's larger Cold War strategy. Thus, this alignment was closer to a makeshift convenience.

The conventional alliance mechanism rarely works in the relation between a state and a non-state actor. For example, despite a huge asymmetry, both allies abandoned each other and were entrapped by the other partner's activities. The U.S. abandoned Afghan Arabs after the Afghanistan War and the Osama bin Laden-led al-Qaeda not only abandoned its former ally but even attacked its former ally in Africa in 1998 and the American mainland in 2001. Afghan Arabs were entrapped by the great powers' wars in Afghanistan and the U.S. was entrapped by Islamic fundamentalists' holy war. This bond arrangement is the most vulnerable to collapse because of its tactical and makeshift nature.

The Syrian Kurds-U.S. alliance provides an empirical case to make the Quadrant C. These two actors were not treaty-based and faced a lack of multiple levels of communication due to their makeshift bond. The Syrian Kurds remained a non-state actor, aspiring to full autonomy but the U.S. was keen on winning the warfare to maintain the American-led international order. Dissimilar objectives between two distinct actors made their relations more asymmetric.

\section{TRACING THE ROK-U.S. ALLIANCE and EXPLAINING ITS LOGIC OF SURVIVAL}

In contrast with the case of the Syrian Kurds, South Korea benefitted from more symmetric power parity and better functioning institutionalization even under the Trump administration's policy to bash allies, explaining the logic of alliance survival. First, regarding power parity, the ROK-U.S. alliance has evolved into a more symmetric alliance over the last seven decades to the extent to seek its Wartime Operational Control. South Korea's growing capabilities contribute to more symmetry. South Korea ranks as the $10 \mathrm{~h}$ largest economy in the world. South Korea also has the status of the 6th biggest power in the world (Global Fire Power 2021). Moreover, South Korea is not a weak power anymore but one of the strong middle powers in the world enough to seek the New Southern Policy. South Korea's prestige in the world is gaining ground and Seoul is continuously asked to engage in international politics more like the QUAD Plus. 
Second, in terms of the nature of the bond, the ROK-U.S. alliance remains functionally institutionalized. In contrast to the U.S.-Syrian Kurds, ROK-U.S. relations are secured by a treaty. These two allied states share democracies as a political system and have communicated through multiple levels, political, cultural, and economic, thereby making the level of institutionalization more robust. What matters is that this condition was not created all at once but evolved through the internal development of South Korea and the long process of institutionalizing efforts with the allied state. The following section deals with this process of alliance evolution, making the alliance less vulnerable to an unexpected emergence of the policy to bash allies.

\section{The 1945-1950 Period (The Case C Mechanism): The U.S.'s Abandonment}

Although the U.S.'s betrayal may be seen as outlying behavior, it could happen in other cases as well under the functional mechanism of condition C. In particular, the U.S.'s betrayal of its Kurdish ally in Syria is sufficient enough to give lessons to South Korea in the sense that this case seems more likely to make North Korea misperceive the U.S.'s behavior as a lack of commitment to its ally. This misperception is what happened in 1950 indeed just before the outbreak of the Korean War.

The early days of ROK-U.S. relations, historically, were quite similar to the situations of condition C. Korea's Joseon Dynasty, a weakening country faced by global imperialism, encountered the U.S., a fast-growing great power in the 19th century, which served as a huge asymmetry. Korea's Joseon was reluctant to align itself with the unfamiliar U.S., but its growing push compelled both countries to make the Treaty of Peace, Amity, Commerce, and Navigation in 1882 (Treaties and Conventions 1889, 216-221). Although this treaty was not based on a security partnership, this served as the first diplomatic treaty between the two states and initiated a bond. This relationship, however, failed to endure under a similar logic that the Syrian Kurds faced. Joseon Korea was not an equal partner to the U.S. and furthermore, the two countries' relations were far from institutionalized. Although this treaty was made primarily by the U.S.'s enthusiasm, the U.S. unilaterally neutralized it when Japan attempted to make Joseon Korea its protectorate in 1905 . The abandonment clearly shows how tactically driven this treaty was, not strategically. Seen in this light, Joseon Korea was entrapped by a growing Western power's ambition and was abandoned by her partner in an urgent moment. Thus, the temporary bond between the two states was simply out of sight when imperialist Japan appeared.

In the meantime, great power politics entrapped Korea again right after World War II. When Japan ended its rule over Korea in 1945, following its defeat in World 
War II, the Korean Peninsula was divided into two Koreas by the great powers, creating condition C similar to the Syrian Kurds. North Korea was under the Soviet sphere of influence, while South Korea was under the U.S. (U.S. DoS 2020). The U.S.'s sphere of influence on South Korea encouraged the two countries to form a security bond although this relationship remained far from a formal alliance. The problem is that the relations were purely asymmetrical. Korea became independent from the Japanese rule on August 15, 1945, but South Korea was under the authority of the U.S. Army Military Government (AMG) from 8 September 1945 to 15 August 1948. In this sense, the nature of the two states' bonds was again subject to power asymmetry. To make matters worse, the security partnership between these two states was rarely institutionalized.

Before the Korean War, the U.S. had served as a temporary partner to the ROK despite its asymmetric nature. Regardless of its asymmetric nature, at least one thing seemed for sure: the U.S. was far from being an enemy and was closer to being a security partner. When World War II was over, the U.S. put South Korea under its military administration until the ROK's foundation in 1948. Thus, American troops were stationed on South Korean soil. Foreign troop presence serves as a manifest indicator of a firm security partnership to the outside. As soon as the ROK was founded, it established foreign relations with the U.S., which contributed to maintaining a key partnership between the two states. The presence of American troops, 77,000 at peak time, on South Korean soil made both states more cooperative economically and militarily in America's efforts to deal with threats from North Korea and the Soviet Union (Stueck and Yi 2010, 180).

In practice, however, great power politics helped shape the temporary bond between the two states and in so doing, established relations that were not only asymmetrical in nature but also rarely institutionalized. Meanwhile, the ROK, which was newly established in the South in 1948, officially made diplomatic relations again with the U.S. in 1949. The formation of diplomatic relations between the two countries contributed to making the bond more institutionalized but was far from a fully realized institutional alliance. When the U.S. AMG was functional, the U.S. was enthusiastic to support its partner. As the U.S. ended its military government in South Korea, however, it began to weaken its partnership and paid less attention to South Korea. Accordingly, the U.S. withdrew its main troops from South Korea in June 1949.

U.S. military withdrawal, however, was only a symptom of the upcoming serious abandonment of the ROK. On January 12, 1950, less than a year after its withdrawal, Washington announced the Acheson Line, named after then-U.S. Secretary of State (Steele 2000). The Acheson Line showed the U.S. line of defense from the Aleutian Islands to the Philippines in the Pacific. Japan was clearly 
included in the Acheson Line but the ROK was excluded. ROK President Rhee took the U.S.'s abandonment as a serious threat to its security and rushed to ask that the U.S. include the ROK while trying to meet then-Secretary Acheson and in a letter of request sent to Washington (Ko 2018). The "infamous" announcement by Secretary Acheson, however, was sufficient enough to give a false signal to North Korea that the U.S. would be unwilling to guarantee the ROK's security at any event (Weathersby 1999, 93).

The withdrawal of American troops from South Korean soil in 1949 clearly showed how weak the ROK-U.S. relationship was in nature back then. American troops' withdrawal might have been a sign of the prevalence of its upcoming harsh betrayal, which excluded the ROK from the American defense line through a 1950 announcement. When North Korea realized that the U.S. had abandoned the ROK, North Korea invaded the ROK without hesitation.

It seemed to be certain that in 1950, before the Korean War, the ROK and the U.S. maintained an allied relationship. The U.S., however, failed to function as a security guarantor to her partner. On June 25, 1950, less than five months after the announcement of the Acheson Line, North Korea invaded the ROK, leading to the outbreak of the Korean War where around 3 million civilians were killed. This example serves as a typical case to show how vulnerable non-institutionalized bonds are, particularly in non-institutionalized asymmetric relations. The withdrawal of American troops and the exclusion of South Korea from the Acheson Line remained unguarded under the conditions of power parity and non-institutionalization.

The ROK was entrapped by great power politics after World War II, leading to the division of the Korean Peninsula. The U.S., one of these great powers, abandoned its partner in the South. What made that happen? The ROK remained weak as an asymmetric partner to the U.S. and the ROK-U.S. bond had not been institutionalized in the transitional period from Korea's independence to the outbreak of the Korean War. In this regard, the Korean War was a tragedy made under condition C. This tragedy resulted in a painful lesson for the ROK. All this explains why Seoul has tried harder to make the ROK-U.S. relationship more institutionalized, which gradually converted the mechanism into condition D. In particular, this harsh experience explains why then-ROK President Rhee tried his best to institutionalize its allied relationship with the U.S. in 1953 after the Korean War.

As time has passed, the ROK-U.S. alliance has become firmly institutionalized and the ROK has increased its prominence as a growing middle power in the world, contributing to making the alliance less asymmetric. The institutionalized alliance between the ROK and the U.S. created a totally different 
posture from the non-institutionalized form. The former is less vulnerable to abandonment than the latter. In the post-Korean War period, the alliance mechanism of the ROK-U.S. had transformed the logic of C into D over time.

\section{The Post-Korean War Period: The Case D Mechanism}

The Quadrant ' $D$ ' mechanism began to emerge after the Korean War and continued to 1996 when South Korea became one of the OECD (Organization for Economic Cooperation and Development) members (IPS 1996). These non-institutionalized relations made the U.S. abandon the ROK, thus, allowing the communist North to invade the South in 1950. The ROK's harsh experiences have encouraged the ROK-U.S. relations to be more institutionalized as time has passed. First, the ROK and the U.S. became more institutionalized militarily and organizationally through the window of opportunity in the Korean War. Unlike the U.S.-U.K. relations, their relations were not embedded in a shared culture. When the Korean War broke out, however, both states shared a clear, common goal, which was to achieve freedom by defeating the communists. As a result, the ROK willingly integrated its military organization into the U.S. under the entity of the United Nations Command (UNC). Then-ROK President Syngman Rhee allowed his soldiers to fight with American soldiers under the Operational Control (OPCON) of the U.S. General Douglas MacArthur, the UNC Commander during the Korean War (Chung 2013, 2).

Second, South Korea was eager to make ROK-U.S. relations more institutionalized after the Korean War, boosted by its tragic experience of the U.S.'s abandonment before the outbreak of the Korean War. President Rhee feared that the ROK could again be in danger of survival without a more institutional form of alliance. To that end, he made tremendous efforts to make a formal, institutional alliance with its American ally. As a result, the Mutual Defense Treaty between the two states was signed in 1953, which solidified their relationship as an institutional military alliance. As time went by, the ROK-U.S. alliance became more institutionally integrated, and in being so, its scope expanded from military to economic, strategic, and even cultural.

The asymmetric nature of the alliance, however, has made the ROK vulnerable to coerced entrapment. In the 1960s, the ROK remained weak militarily and economically. Thus, the ROK had no choice but to be entrapped by the U.S.-led Vietnam War from the mid-1960s to the early 1970s. Meanwhile, South Korea continued its economic development and finally joined the OECD as a growing middle power in 1996. Thus, the U.S.-South Korea alliance has been characterized by both a high degree of institutionalization and narrowing the power gap. Thus, the alliance remains less vulnerable to abandonment and entrapment. 
In this period, the risk of abandonment by the U.S. was about to emerge but an institutionalized framework prevented this policy from being applied in practice. In May 1977, the Carter administration decided the withdrawal of American group troops in South Korea, and this plan was embodied through the 10th SCM two months later. Washington originally planned to withdraw 7,000 troops by 1978, 9,000 by 1980, and all remaining ground troops by 1982 (Cho 2018, 73). Washington saw American troops fixed on the Korean Peninsula as unhelpful for maximizing its national interest in a situation where South Korea remained weak, which served as an asymmetric ally. Put simply, the Carter administration was eager to avoid entrapment.

Meanwhile, a high degree of institutionalization motivated America's other agencies to oppose this plan, restraining the abandonment implementation. The U.S. Joint Chiefs of Staff (JCS) opposed Carter's plan to withdraw ground troops in South Korea. When Carter pushed hard, the JCS favored a gradual withdrawal, not a rapid phase (Wood 1996, 101). The CIA also saw this plan as "dangerous risks" (Wood 1996, 102). To top it off, the U.S. Congress did not approve Carter's plan, which forced the first plan to be revised (Cho 2018). As a result, Carter's plan failed to be implemented according to the original plan. An institutionalized alliance setting allowed a strong internal opposition to emerge. When the Reagan administration was launched in 1981, it began to entirely reverse the withdrawal plan and guaranteed security commitment by visiting the DMZ in 1983 (Canon 1983). This posture change shows that the risk of abandonment swayed by a certain administration can be prevented by the institutionalized function.

\section{The Middle Power Period: The Emergence of ' $\mathrm{B}$ ' Mechanism}

South Korea has been increasing the status of middle power since 1996. As a result, the ROK-U.S. alliance has gradually evolved into the logic of condition B and continues to this day. As the ROK rose to the status of a middle power, it became more confident and autonomous. The institutionalized alliance mechanism has prevented the stronger ally, the U.S., from abandoning South Korea. Whenever North Korea provoked conflict, ranging from guerilla infiltrations to attacks such as the ROKS Cheonan incident in 2010 to nuclear ambition, the U.S. strongly assisted its South Korean ally. In practice, far from the fear of abandonment, the U.S. has provided South Korea with military and economic support, which helped the letter rise to a middle power in the 21st century.

The power asymmetry between the two allies has reduced over time. The U.S.'s Terminal High Altitude Area Defense (THAAD) was deployed in 2017 after a 2016 agreement by the government in Seoul in an effort to step up its security 
(Sankaran, 2017). At the same time, the deployment of THAAD was regarded as crucial for the U.S.'s vital interests aimed at containing China. Meanwhile, the "Three Axes System" against North Korea's nuclear threat by the modernized and technological ROK military is interoperable with America's THAAD, which shows a role of power parity.

Over time, the ROK has further narrowed its power asymmetry to the U.S. thanks to its growth in both military and economic sectors. In 2021, South Korea was categorized as a developed economy by the U.N. Conference on Trade and Development (The Korea Times July 4, 2021). As of 2021, South Korea also ranked 6 th in the world when it comes to military strength (GFP 2020). The ROK, which has become more symmetric than before, is not only more autonomous but also more capable. By the same token, when a stronger ally pushes a once-weaker ally, which is no longer weak, to share defense-costs, the latter is likely to resist. This is exactly what happened in the defense-cost sharing negotiation between the ROK and the U.S. in 2019-2020.

The middle power period is characterized by the condition favorable to maintain alliance cohesion. Meanwhile, Seoul faced the Trump administration with a different posture towards allies. It seemed clear that the Trump administration trivialized the U.S.-ROK alliance while the "America First" policy downplayed the value of the alliance. In this period, Trump undermined the U.S.-ROK alliance through a raft of bashing acts. Trump did not hesitate to threaten to withdraw American troops from South Korea while demanding a huge cost-sharing increase on the Special Measures Agreement (SMA) (Fuchs and Lee 2020). Paradoxically, Trump stressed "a special and close friendship" with Kim Jong-un, a supreme leader of North Korea, whose threat was the origin of forming the ROK-U.S. alliance (Byun 2020). On October 1, 2019 when Pyongyang was preparing for the launch of the new Submarine-Launched Ballistic Missile (SLBM), Trump "showed no interest," which downplayed the threat from North Korea (Walcott and Bennett 2019). Bashing allies and staying close to enemies forced the ROK-U.S. alliance into deadlock.

The seemingly ironclad alliance met with stumbling cohesion mostly driven by the "America First" policy and its lack of recognition for a traditional enemy, such as North Korea. To top it off, the seemingly temporary détente on the Korean Peninsula in the 2018-2020 period made the U.S.-ROK alliance appear less vital. South Korea and the U.S. stopped key joint exercises and training during this period in particular due to-Trump's negligence of allies (Axelrod 2019).

Despite Trump's signal to downplay and abandon a South Korean ally, U.S.-South Korea relations did not lead to alliance decoupling thanks to the logic of power parity and institutionalization. South Korea as a leading middle power, 
implying a narrowing power gap, could afford to do more for its American ally in this period. When the U.S. struggled with the Iraq War due to its changing nature of unconventional warfare, South Korean forces had the capability to fight together with their American ally on the battlefield from 2003 to 2008 (Ban 2017). A growing power also allows Seoul to implement the New Southern Policy. What matters to the U.S. in this outward policy is that this policy has the potential to link with the U.S.-led Indo-Pacific Strategy, which shows South Korea's value as an ally (U.S. DoS 2020). What is noteworthy in this period is that Washington wants South Korea to play a bigger role in maintaining security in the region as well as on the Korean Peninsula thanks to its enhanced prestige. Despite Seoul's reluctance, Washington is eager to launch "Quad Plus" including South Korea, which implies alliance decoupling is not in America's interest (Do 2020; Byun 2020).

Furthermore, the institutionalized setting encouraged other agencies beyond the White House to raise their voices to prevent alliance decoupling. When facing a shaky alliance by Trump's bashing, Korea-U.S. Alliance Foundation was at the forefront to make the U.S.-South Korea alliance maintain cohesion. For instance, on October 13, 2020, prior to the 52nd SCM (Security Consultative Meeting), the Chairman of the Foundation sent open letters to both the U.S. Secretary of Defense and ROK Minister of National Defense while encouraging the two allies to step up its efforts to deal with many issues together (Kim 2020). On November 17, 2020, General Abrams, Commander of CFC and U.S. Forces Korea (USFK) invited South Korea's Assembly members and maintained that "our commitment to the ROK-US alliance remains ironclad, unbreakable and COVID-proof" (USFK 2020). Furthermore, in December 2020, the U.S. Congress passed the 2021 NDAA (National Defense Authorization Act) which included an item to bar American troop reductions in South Korea "without significant justifications" (Gould 2020). When Trump vetoed this bill, the U.S. Congress overrode his veto in huge numbers (Daly 2021). All in all, the logic of power parity and institutionalization prevented alliance decoupling from happening.

The ROK-U.S. alliance provides an empirical case on when alliances survive and how they evolved from Quadrant C to D into B. These two actors were formally linked through a treaty on the outset and their allied relations have become more cohesive through multiple levels of coordination as time went by. As South Korea rises to a leading middle power, its relations with the U.S. have become more symmetric than before. That explains why at the Summit on May 21, 2021, the two leaders of South Korea and the U.S. vowed to coordinate policy between Seoul's New Southern Policy and Washington's Indo-Pacific Strategy (The White House May 21, 2021). These two conditions boil down to the logic of alliance survival 
under the Trump administration's attempt to abandon its ally.

\section{CONCLUSION: POLITICAL AND POLICY IMPLICATIONS}

This paper compares the case of the Syrian Kurds with the case of South Korea while coming up with remedies to minimize alliance vulnerability. Meanwhile, some could raise questions on what lessons South Korea can learn from the Syrian Kurds case in a situation where the ROK-U.S. maintains a treaty ally between states but the Syrian Kurds-U.S. simply remains a non-treaty ally between a state and non-state. Trump administration's policy to bash allied-states or non-states, however, becomes a precedent to show that even treaty allies could be decoupled by a stronger ally's unilateral policy change. In the Trump era, the U.S. bashed even major allies harshly, including the NATO and Japan that had maintained more cohesive alliances than South Korea. Thus, South Korea needs to figure out which is the best condition and which is the worst case in an effort to take precautions to lessen alliance vulnerability in the sense that the ROK-U.S. alliance serves as a key mechanism towards peace and stability on the Korean Peninsula.

Moreover, although South Korea was historically under the same mechanism as the Syrian Kurds in 1945-1950, it tends to take ROK-U.S.'s cohesion for granted. Even treaty allies need smart policies or strategies towards alliance management. The findings show that more symmetric power and more consolidated institutionalization can diminish alliance vulnerability, shedding some light on how South Korea takes the initiative of alliance politics. In particular, the findings matter because the ROK-U.S. alliance has leeway to be more institutionalized and symmetric. In this vein, the ROK-U.S. Summit, which took place on 21 May 2021, can contribute to this line of effort by making the two states more binding institutionally and more symmetric through shared missions.

This analysis not only provides insight into academic accumulation on international security but also has political and policy implications. First, as opposed to Trump's expectation, the U.S.'s threatening signal that could abandon allies is likely to neither "make America Great Again" nor help America's role for international governance by worsening weak actors' animosity to strong actors. Weak powers have no choice but to become entrapped by great power politics and run the risk of abandonment. The U.S.'s betrayal of the Syrian Kurds shows that this tragic mechanism is still at work in the world, which increases fear and suspicion. A lack of confidence in the U.S. seems more likely to make its War on Terror harder. Local allies are vital for a hegemonic power to win small wars, such as the one against the IS. The U.S.'s abandonment, however, could make local 
allies that have fought on the side of the American military more fearful and thus, stay away from their American ally. Being defeated in these wars seems likely to render the U.S. hegemony less sustainable.

Second, contrary to conventional wisdom of explaining alliance politics primarily in terms of power and threat, institutionalization could be more pivotal. Regardless of regime type, condition $C$ can happen, which means even democracies can impulsively abandon their allies. Meanwhile, institutionalization can function as the prevention of abandonment. Once an alliance is made, allies need to make it institutionalized as soon as possible through official memorandums, press conferences, and other interdependent activities. Asymmetrical alliances, in particular, can be the most vulnerable without becoming institutionalized. The increase of audience through the formation of institutional alliances is more likely to contribute to guaranteeing security. Weak powers need to try their best to make the bond more institutionalized. The ROK's efforts made after the Korean War could serve as a role model for them.

Third, it clearly illustrates that there exists no permanent alliance in world politics. The U.S.'s abandonment of its Kurd ally clearly shows to the world, particularly its numerous other allies, how unreliable alliances are. Similarly, this case reveals that the logic of abandonment is still largely at work in the present world, promoting the doctrine of self-reliance. Too much emphasis on the policy of self-reliance will make states less cooperative with each other, which leads to the risk of throwing international security into danger.

Finally, this examination provides insight into future ROK-U.S. alliance through lessons learned from the case of the Syrian Kurds (Park 2019; The Economist 2019). The newly launched Biden administration stresses "American is back" which implies alliance is back to normal (Borger 2020). Bashing allies, as shown in the Trump administration, could return anytime when domestic politics is changed in the U.S., though. Thus, South Korean policymakers need to see a longer and comprehensive perspective to make the U.S.-ROK alliance continue to be cohesive, simply beyond a narrow policy on an administration basis.

The logic of power parity and institutionalization should be reflected when stepping up measures to strengthen the alliance. The inherent logic of power parity is driven by the potential to increase the role of South Korea, a middle power, in guaranteeing America's interests simply beyond security on the Korean Peninsula. Seen in this light, Seoul's willingness to do more for regional security can help make the U.S.-ROK alliance more cohesive through more active policies to join Quad Plus, be synchronized with Freedom of Navigation Operations 
(FONOPs), and contribute to implementing the Indo-Pacific Strategy. ${ }^{5}$ A more assertive role of South Korea will contribute to a more symmetric alliance at the end of the day.

Simultaneously, how to render alliances more institutionalized needs to be taken into consideration. To that end, the level of interdependence needs to be increased from defense to economy even to culture and society. In addition to Track 1 talks, Track 1.5 dialogues need to be designed to deal with many issues including nuclear extended deterrence, future alliance framework, and the North Korea nuclear program. Public diplomacy needs to be in the works as well. For example, the ROK forces can invite American citizens to their military bases, and reciprocally, the U.S. forces can invite Korean citizens to their bases such as the USFK in Pyeongtaek to promote their understanding of the importance of the alliance.

It is necessary to preserve the institutionalized mechanism in the ROK-U.S. alliance. In contrast with the Trump administration, the Biden administration is eager to bring the alliance back. Seoul should make the best use of this rising opportunity to make the ROK-U.S. alliance more binding institutionally. At the same time, reducing the power gap between allies seems more helpful for alliance maintenance. When the ROK's power or prestige becomes weak and thus, a less symmetric partner, the logic of reciprocity seems likely to gradually disappear. ${ }^{6}$ In this sense, the ROK, currently a middle power, continues to step up its efforts to increase its power and prestige. What matters more is that these two drivers, power and institutionalization, are synergetic. Seoul's increased role for regional security will help the ROK-U.S. alliance be more institutionalized. When both variables are met, the ROK-U.S. alliance can evolve into consolidating condition B. When even one of two variables mentioned above falters, however, the alliance would begin to be less cohesive by degenerating into the $\mathrm{D}$ logic.

These alliances are often faced with transitional periods and when they are, they will turn out to be two types: evolution or degeneration. First, when a weaker ally becomes stronger and gradually more symmetric to a stronger ally, condition $B$ is met and thus, alliances evolve and become firmer. Second, when a weaker ally remains weak and asymmetric, the bond between the two allies begins to stumble, which is only exacerbated by policy differences and security-environment changes. In this case, the overall condition mechanism seems most likely to degenerate from condition D to condition C. It remains to

\footnotetext{
${ }^{5}$ For the Indo-Pacific Strategy see The U.S. Department of Defense (2019).

${ }^{6}$ Park (2019) argues that the ROK needs to learn the lesson from the U.S.'s betrayal of the Kurds in Syria. Similarly, The Economist (2019, October 19) also maintains that "the betrayal of the Kurds will lead friends and foes to doubt Mr. Trump's America."
} 
be seen which way the ROK-U.S. bond will proceed in the near future but one thing seems near certain. The ROK-U.S. alliance has served as the most important contributor for guaranteeing security and thus, will continue to determine the ROK’s destiny significantly. 


\section{REFERENCES}

Axelrod, Joshua. 2019. "Trump administration to end major military exercises with South Korea: report." MilitaryTimes. (1 March). https://www.militarytimes.com/news/pentagon-congress/2019/03/01/tr ump-admin-to-end-major-military-exercises-with-south-korea-report/ (December 30, 2020)

Aziz, Lara. 2020. "The Syrian Kurds in the US foreign policy: long-term strategy or tactical ploy?" Note d'analyse no. 66. http://cecrilouvain.be/wp-conten t/uploads/2020/01/Note-danalyse_LaraAziz_Version-finale.pdf (July 2, 20 21).

Ban, Kil Joo. 2017. Chagŭn kŏin: chunggyŏn'gukka han'gugŭi anjŏngwa chakchŏn sŏnggong mek'onnijüm (The Little Giant: Tracing How to Succeed Counterinsurgency in Iraq by South Korean Forces) Seoul: BookKorea.

Ban, Kil Joo. 2020. "Jammed Allies: The Ironclad ROK-U.S. Alliance and China as a Gray Actor." Asian Politics \& Policy 12(3), 337-361.

Barnes, Julian E. \& Eric Schmitt. 2019. “Trump Orders Withdrawal of U.S. Troops From Northern Syria." The New York Times. (October 13). https://www.nytimes.com/2019/10/13/us/politics/mark-esper-syria-kur ds-turkey.html (November 2, 2019).

Benson, Brett V. 2011. "Unpacking Alliances: Deterrent and Compellent Alliances and Their Relationship with Conflict, 1816-2000" The Journal of Politics 73(4), 1111-1127.

Bergen, Peter L. 2002. Holy War, Inc.: Inside the Secret World of Osama bin Laden. New York: Touchstone.

Borger, Julian. 2020. "Biden says 'America is back' at the head of the table - but is that a good thing?" The Guardian. (November 26). https://www.theguar dian.com/us-news/2020/nov/26/biden-america-is-back-foreign-policydiplomacy (December 30, 2020).

Bosack, Michael M. 2020. "Ameliorating the Alliance Dilemma in an Age of Gray-Zone Conflict.” Naval War College Review 73(4), 1-22.

Burc, Rosa. 2019. President Recep Tayyip Erdogan's war is an ethnonationalist attack on Kurds and their aspirations. The New York Times. (October 22). https://www.nytimes.com/2019/10/22/opinion/erdogan-kurds-syria.ht $\mathrm{ml}$ (November 1, 2019).

Byun, Duk-kun. 2020. "Trump, Kim both promise lasting friendship, but only time will tell: Woodward.” Yonhapnews Agency. (September 15). https://en.yna.co.kr/view/AEN20200915000300325 (December 30, 2020). 
Byun, Duk-kun. 2020. "U.S. commission claims launch of 'Quad Plus' denied by U.S. gov't.” Yonhapnews Agency. (December 29). https://en.yna.co.kr/vie w/AEN20201203010100325 (December 29, 2020).

Cannon, Lou. 1983. "Reagan Takes Tour of DMZ." The Washington Post. (November https://www.washingtonpost.com/archive/politics/1983/11/13/reagan-ta kes-tour-of-dmz/f7cdd513-7e89-4de7-b1d9-d1c038bec81e/ (December $29,2020)$.

Cha, Victor D. 2019. "The Unintended Consequences of Success: U.S. Retrenchment from Korea?” The Korean Journal of Defense Analysis 31(2), 165-191.

Cho, Kwanhaeng. 2018. "K'at'ŏ haengjŏngbunŭn wae chuhanmigun ch'ŏlsujŏngch'aegŭlsujŏngayŏnnŭn'ga?” (Why did the Carter Administration revise the decision to withdraw U.S. troops from Korea?), Kukkajölyak. 24(4), 71-101.

Chung, Kyung-young. 2013. "The Year 2015 or After: Transition of Wartime Operational Control, Self-esteem of the Republic of Korea, and Trust-building Process.” EAI Issue Briefing. No. MASI 2013-03. http://www.eai.or.kr/main/english/research_view.asp?intSeq=17739\&co $\mathrm{de}=94 \&$ keyword_option=\&keyword=\&gubun=research (December 31, 2020).

Daly, Matthew. 2021. "Congress overrides Trump veto of defense bill." DefenseN ews. (January 1). https://www.defensenews.com/congress/budget/2021/ 01/01/congress-overrides-trump-veto-of-defense-bill/ (January 5, 2021).

Do, Je-hae. 2020. "Quadrilateral alliance and Korea." The Korea Times. (October 9). https://www.koreatimes.co.kr/www/nation/2020/10/356_297283.html (December 29, 2020).

Emel, Parlar Dal. 2016. "Impact of the transnationalization of the Syrian civil war on Turkey: conflict spillover cases of ISIS an PYD-YPG/PKK." Cambridge Review of International Affairs 29(4), 1396-1420.

Fearon, James D. 1997. "Signaling Foreign Policy Interests: Tying Hands versus Sinking Costs." The Journal of Conflict Resolution 41(1), 68-90.

Fuchs, Michael and Haneul Lee. 2020. "Bridging the Divide in the U.S.-South Korea Alliance.” Center for American Progress. (November 23). https://www.americanprogress.org/issues/security/reports/2020/11/23/ 493041/bridging-divide-u-s-south-korea-alliance/ (December 30, 2020).

Gerring, John. 2007. Case Study Research. Principles and Practices. Cambridge: Cambridge University Press.

GFP. 2020. "2020 Military Strength Ranking.” https://www.globalfirepower.com/ 
countries-listing.asp (December 30, 2020).

Gibler, Douglas M. and Scott Wolford. 2006. "Alliances, The Democracy: An Examination of the Relationship between Regime Type and Alliance Formation.” Journal of Conflict Resolution 50(1), 129-153.

Global Fire Power. 2021. "2021 Military Strength Ranking." https://www.globalfirepower.com/countries-listing.php (30 June, 2021). Gol, Jiyar. 2019. Syrian Kurds: “The world has closed its eyes on us.” BBC News. (October 27). https://www.bbc.com/news/world-middle-east-50181855 (November 24, 2019).

Goldstein, Avery. 1995. "Discounting the Free Ride: Alliances and Security in the Postwar World." International Organization 49(1), 39-71.

Gould, Joe. 2020. "Defying Trump, House approves defense bill with veto-proof majority." DefenseNews. (December 8). https://www.defensenews.com/ congress/2020/12/08/defying-trump-house-oks-defense-bill-335-78/ (De cember 30, 2020).

Hubbard, Ben \& Gall, Carlotta. 2019. "Turkey Launches Offensive Against U.S.-Backed Syrian Militia." The New York Times. (October 9). https:/www.nytimes.com/2019/10/09/world/middleeast/turkey-attackssyria.html (November 2, 2019).

Hubbard, Ben, Charlie Savage, Eric Schmitt and Patrick Kingsley. 2019. "Abando ned by U.S. in Syria, Kurds Find New Ally in American Foe." The New York Times. (October 13). https://www.nytimes.com/2019/10/13/world/middl eeast/syria-turkey-invasion-isis.html (November 24, 2019).

IPS. 1996. "South Korea-Economy: Is Seoul Ready to Join OECD' Elite Club?" (November

http://www.ipsnews.net/1996/11/south-korea-economy-is-seoul-ready-t o-join-oecds-elite-club/ (December 30, 2020).

Johnson, Jesse C. 2017. “External Threat and Alliance Formation." International Studies Quarterly61(3), 736-745.

Joint Communique of the United States of America and the People's Republic of China. 2019. TDP (Taiwan Document Project). (February 28). www.taiwandocuments.org/communique01.htm (November 18, 2019).

Jung, Da-min. 2019. "South Korean general to lead combined forces command."

The Korea Times. (June 3). https://www.koreatimes.co.kr/www/nation/ 2019/06/205_269982.html (December 29, 2020)

Kim, Tongfi. 2011. "Why Alliances Entangle But Seldom Entrap States.” Security Studies 20(3), 350-377.

Kimball, Anessa L. 2010. "Political Survival, Policy Distribution, and Alliance Formation.” Journal of Peace Research 47(4), 407-419. 
Kim, Gwi-gun. 2020. "Hanmidongmaengjaedan "hanmidongmaeng maeu chun gyosigi' '*hanmi kukpangjanggwane sŏhan” (Korea-US Alliance Foundati on send open letters to defense chiefs of the two countries, which said 'thi $\mathrm{s}$ is a critical moment to the U.S.-ROK alliance'). Yonhapnews Agency. (Oc tober 13). https://www.yna.co.kr/view/AKR20201013151200504?input=11 95m (December 30, 2020).

Kirby, Jen. 2019. 9 questions about Turkey, Syria, and the Kurds you were too. Vo $x$. (October 16). https://www.vox.com/world/2019/10/16/20908262/turkey -syria-kurds-trump-invasion-questions (November 1, 2019).

Ko, Soo-Suk. 2018. "Remember the Acheson Line." Korea JoongAng Daily (January http://koreajoongangdaily.joins.com/news/article/article.aspx?aid=3042 766 (November 25, 2019).

Kupchan, Charles A. 1988. "NATO and the Persian Gulf: examining intra-alliance behavior." International Organization 42(2), 317-346.

Lamothe, Dan. 2019. “'I can't even look at the atrocities': U.S. troops say Trump's Syria withdrawal betrayed an ally." The Washington Post. (October 15). https://www.washingtonpost.com/world/national-security/i-cant-even-1 ook-at-the-atrocities-us-troops-say-trumps-syria-withdrawal-betrayed-a n-ally/2019/10/15/4e79b600-eeca-11e9-b648-76bcf86eb67e_story.html (November 2, 2019).

Merriam-Webster. https://www.merriam-webster.com/dictionary/alliance?src =search-dict-box (November 13, 2019).

Morrow, James D. 1994. "Alliances, Credibility, and Peacetime Costs." Journal of Conflict Resolution 38(2), 270-297.

Morrow, James D. 2000. "Alliances: Why Write Them Down?" Annual Review of Political Science 3(1), 63-83.

Niou, Emerson M. S. and Sean M. Zeigler. 2019. "External Threat, Internal Rivalry, and Alliance Formation." Journal of Politics 81(2), 571-584.

O'Shea, Paul and Sebastian Maslow. 2020. "Making the alliance even greater': (M is-)managing U.S.-Japan relations in the age of Trump." Asian Security. Pu blished online November 5, 2020. https://doi.org/10.1080/14799855.2020. 1838486.

Park, Inwhee. 2019. "K'urŭdŭjok sat'aeŭi kyohun, hanbandonŭn yeoein'ga” (The ROK also need to learn the lesson from the Kurds incident). Joongangilbo. (October 25). https://news.joins.com/article/23614544 (November 3, 2019).

Park, Seo-Hyun. 2017. "Rhetorical entrapment and the politics of alliance cooperation: explaining divergent outcomes in Japan and South Korea 
during the Iraq War." International Relations 31(4), 484-510.

Plümper, Thomas and Eric Neumayer. 2014. "Free-riding in alliances: Testing an old theory with a new method." Conflict Management and Peace Science 32(3), 247-268.

Porter, Patrick. 2019. Blunder: Britain's War in Iraq. Oxford: Oxford University Press.

Richter, Andrew. 2021. "NATO in the age of Trump: Alliance defense spending during the Trump presidency." Comparative Strategy 40(3), 285-304.

Sankaran, Jaganath. 2017. Missile defense and strategic stability: Terminal High Altitude Area Defense (THAAD) in South Korea. Contemporary Security Policy 38(3), 321-344.

Schweller, Randall. 1994. "Bandwagoning for Profit: Bringing the Revisionist State Back in." International Security 19(1), 72-107.

Smith, Alastair. 1998. "Extended Deterrence and Alliance Formation." International Interactions 24(4), 315-343.

Snyder, Glenn H. 1984. "The Security Dilemma in Alliance Politics.” World Politics 36(4), 461-495.

Snyder, Glenn H. 1997. Alliance Politics. Ithaca, New York: Cornell University Press.

Statistics Times. GDP (Nominal) Ranking 2019. http://statisticstimes.com/economy /projected-world-gdp-ranking.php (November 21, 2019).

Steele, Bruce. 2000. "Korea: Historians debunk some popular myths about the K orean War." University of Pittsburgh. (June 22). https://www.utimes.pitt. edu/archives/?p=3016 (December 30, 2020).

Stueck, William and Boram Yi. 2010. "An Alliance Forged in Blood': The American Occupation of Korea, the Korean War, and the US-South Korean Alliance." The Journal of Strategic Studies 33(2), 177-209.

The Economist. 2019. "Vlad the dealmaker Russia and Turkey agree to carve up norther Syria." (October 24). https://www.economist.com/middle-eastand-africa/2019/10/24/russia-and-turkey-agree-to-carve-up-northern-sy ria (January 1, 2021).

The Guardian. 1999. "Frankenstein the CIA created." (January 17). https://www.theguardian.com/world/1999/jan/17/yemen.islam (November 24, 2019).

The Korea Times. 2021. "UN agency upgrades Korea to developed economy." (July 4). https://m.koreatimes.co.kr/pages/article.amp.asp?newsIdx=311 548 (July 4, 2021).

The U.S. Department of Defense. 2019. Indo-Pacific Strategy Report. (June 1). https://media.defense.gov/2019/Jul/01/2002152311/-1/-1/1/DEPARTMEN 
T-OF-DEFENSE-INDO-PACIFIC-STRATEGY-REPORT-2019.PDF (November 26, 2019).

The White House. 2021. "U.S.-ROK Leaders' Joint Statement." (May 21). https://www.whitehouse.gov/briefing-room/statements-releases/2021/0 5/21/u-s-rok-leaders-joint-statement/ (July 4, 2021).

Tiezzi, Shannon 2020. "Scott Snyder on Trump, South Korea, and 'America-First' Alliance Policy.” The Diplomat. (August 19). https://thediplomat.com/2020 /08/scott-snyder-on-trump-south-korea-and-america-first-alliance-poli cy/ (December 29, 2020).

Treaties and Conventions: The United States of American and Other Powers. 1889. Washington: Government Printing Office.

U.S. DoS (Department of State). 2020. "U.S. Relations With the Republic of Korea." (September 22). https://www.state.gov/u-s-relations-with-the-republic-of -korea/ (December 30, 2020).

U.S. DoS (Department of State). 2020. "The United States of America and The Republic of Korea on Working Together to Promote Cooperation between the Indo-Pacific Strategy and the New Southern Policy." (November 13). https://www.state.gov/the-united-states-of-america-and-the-republic-of -korea-on-working-together-to-promote-cooperation-between-the-indo -pacific-strategy-and-the-new-southern-policy/ (December 30, 2020).

USFK. 2020. "USFKand UNC Emphasize Commitment to ROK-US Alliance." (November 17). https://www.usfk.mil/Media/Press-Releases/Article/2417050/usfk-an d-unc-emphasize-commitment-to-rok-us-alliance/ (December 29, 2020).

Walcott, John and Brian Bennett. 2019. "Exclusive: Trump Shows 'No Interest' in New North Korea Missile Threat, Prepares Diplomatic Offer." TIME. (October

https://time.com/5692361/trump-north-korea-missile-threat/ (December 30, 2020).

Walt, Stephen M. 1987. The Origins of Alliances. New York: Cornell University Press.

Waltz, Kenneth N. 1979. Theory of International Politics. Reading, MA: Addison-Wesley.

Weathersby, Kathryn. 1999. “The Korean War revisited.” The Wilson Quarterly 23(3), 91-97.

Welle, Deutsche. 2020. "Joe Biden seeks a reset in US-South Korea relations amid North Korea challenges." Taiwan News. (November 13). https://www.taiwannews.com.tw/en/news/4053244 (December 29, 2020).

Wood, Joe. 1996. "A Case Study: Persuading a President: Jimmy Carter and Ameri can Troops in Korea.” NSARCHIVE, https://nsarchive2.gwu.edu//NSAEBB 
/NSAEBB431/docs/intell_ebb_002.PDF (December 29, 2020).

Yeung, Man Fung. 2021. "Seoul as an overzealous ally to the U.S.: Why Washington will not Abandon Seoul." Tamkang Journal of International Affairs 24(3), 43-94.

Yonhapnews Agency. 2020. "S. Korea’s GDP ranks 10th worldwide in 2019.” (May 27). https://en.yna.co.kr/view/AEN20200527001300320 (December 29, 2020).

[Received May 5, 2021; Revised Jul 9, 2021; Accepted Jul 15, 2021] 